\title{
Plant Variety Protection, Private Funding, and Public Sector Research Priorities
}

\section{Mary K. Knudson and Carl E. Pray}

The objective of the Plant Variety Protection Act of 1970 (PVPA) was to increase a firm's ability to capture the returns on its applied breeding research and development (R\&D) investments. Firms were expected to increase their R\&D investments to take advantage of increased returns. Studies have shown that the PVPA has induced the private sector to increase its investments, particularly in soybeans and wheat (Butler and Marion; Perrin, Kunnings, and Ihnen). Recently, Stallman raised the concern that the PVPA may also influence agricultural experiment stations (SAES). She suggests that public R\&D priorities may be shifted away from commodities and research topics that have high social rates of return.

While it is possible that the PVPA will pull research away from the socially optimal allocation of resources, other sources of distortion may be equally important. Political pressure on public research or industry's contributions to public research may lead to too much research on certain topics (Ulrich, Furtan, and Schmitz) or commodities. Another concern is that, in certain commodities, the private sector research is crowding out public research. Both concerns raise the questions of who will teach the next generation of scientists, who will provide varieties when markets are insufficient to induce private research, and who will maintain the competitive structure of agricultural production, inputs, and marketing.

This paper is part of a larger project on the impact of the PVPA and patents on public and private $R \& D$, and on crop yields and genetic

Mary K. Knudson is a visiting assistant professor in the Institute of Public Policy Studies at the University of Michigan. Carl E. Pray is an associate professor in the Department of Agricultural Economics, Rutgers University. Authorship is shared equally.

This research was partially supported by a cooperative agreement between Rutgers University and the Economic Research Service, U.S. Department of Agriculture. The views and errors in this paper are the authors'.

The authors would like to thank Glenn Nelson, Jim Oehmke, John Reilly, and Marie Walsh for their comments. diversity of major field crops in the United States. The primary purpose of this paper is to measure the PVPA's impact on public sector plant breeding. The secondary purpose is to find out whether industry directly influences public research. As a preliminary study, we examine public sector R\&D expenditure patterns on wheat, soybeans, corn, cotton, and sorghum.

\section{Public Sector Resource Allocation and Intellectual Property Rights}

Table 1 shows why some people are concerned. Since 1980 the number of scientists years (SYs) in some of the Agricultural Research Service (ARS) and SAES plant breeding programs have declined. In com, $S Y$ s dropped $22 \%$, the most of the five crops. However, crowding out is most likely to occur in corn because corn attracts more private resources and is growing at a faster rate than the other four crops. Sorghum, too, has a long history of private research and experienced a decline in public sector $S Y$ s. In contrast public SYs have increased in soybeans and wheat, which is where the PVPA strengthened property rights the most. Cotton is an anomaly; it declined even though the PVPA strengthened SAES' ability to appropriate gains.

Table 2 shows that SAES have been acquiring Plant Variety Protection Certificates (PVPCs). SAES started applying for wheat, soybean, and cotton PVPCs in 1970. The first two columns in table 2 show that the public sector acquired the greatest number of PVPCs in soybeans and wheat. No PVPCs were issued for corn or sorghum inbred lines even though these crops were eligible for protection.

The second half of table 2 shows the results of a 1989 ARS survey of SAES on their use and future intentions to use PVPCs and utility patents (UPs). Two-thirds of the SAES currently use PVPCs, but only two more plan to use them 
Table 1. Public and Private Scientists in Applied Research on Selected Crops

\begin{tabular}{llllllrr} 
& \multicolumn{3}{c}{ Public } & \multicolumn{2}{c}{ Private } \\
\cline { 2 - 4 } \cline { 6 - 8 } & 68 & 72 & 80 & 88 & 82 & 89 \\
\hline Corn & 56 & 58 & 68 & 53 & 155 & 257 \\
Sorghum & 12 & 16 & 17 & 14 & 22 & 23 \\
Wheat & 39 & 54 & 58 & 69 & 23 & 25 \\
Cotton & 50 & 43 & 41 & 37 & 17 & 11 \\
Soybeans & 18 & 26 & 42 & 59 & 36 & 60 \\
\hline
\end{tabular}

Source: Public SYs from CRIS; Private Ph.D. SYs from Kalton, Richardson, and Frey.

Table 2. PVPA Certificates and Patents Issued and Intentions of Public Sector for Selected Crops, 1973-89

\begin{tabular}{|c|c|c|c|c|c|c|}
\hline \multirow[b]{3}{*}{ Crop } & \multirow{2}{*}{\multicolumn{2}{|c|}{$\begin{array}{l}\text { PVPCs Issued to SAES } \\
\text { or ARS }\end{array}$}} & \multicolumn{4}{|c|}{ No. of SAES which: } \\
\hline & & & \multirow[b]{2}{*}{ Use PVPA ${ }^{a}$} & \multirow{2}{*}{$\begin{array}{l}\text { Will } \\
\text { Use }^{b}\end{array}$} & \multirow[b]{2}{*}{ Use Patents $^{a}$} & \multirow{2}{*}{$\begin{array}{l}\text { Will } \\
\text { Use }^{b}\end{array}$} \\
\hline & $1973-81$ & $1982-89$ & & & & \\
\hline Corn and sorghum & 0 & 0 & 1 & 5 & 3 & 5 \\
\hline Cotton & 12 & 7 & 4 & 6 & 1 & 5 \\
\hline Soybean & 27 & 59 & 14 & 19 & 1 & 5 \\
\hline Wheat & 29 & 26 & 11 & 17 & 0 & 4 \\
\hline All crops & & & 32 & 34 & 19 & 37 \\
\hline
\end{tabular}

Sources: Columns 1 and 2, "Plant Variety Protection Office Journal." Columns 3-6, Howard J. Brooks, "Questionnaire on Maintenance of Free Exchange of Plant Germplasm," USDA ARS Memorandum, 17 Nov. 1989.

"The number of AES that applied for PVPCs or patents as of 1989.

' The number of AES that stated that future use of plant protection was either definite or probable.

in the future. The number of SAES that plan to use UPs will almost double from nineteen to thirty-seven. The number of SAES using PVPCs and UPs for the major field crops, particularly corn, sorghum, and wheat, will grow more rapidly than the totals. At present only a few experiment stations use UPs on these crops.

\section{Model of Public Research Resource Allocation}

Most economists advise government research administrators to allocate their research resources to maximize expected social benefits from research. But most empirical studies of research resource allocation in the agricultural economics literature assume that research administrators are also influenced by the demands of organized interest groups (Huffman and Miranowski, Hayami and Ruttan, Rose-Ackerman and Evenson). These models assume that research administrators are cost minimizers within a budget that is partly determined by interest groups and politicians's demand for research.

An alternative way to model the supply side is to consider ARS and SAES administrators as budget-maximizing bureaucrats (Ruttan). The director invests his research resources in different commodities to increase his research resources in the future. Major sources of funding are state and federal governments, private industry and royalties from PVPCs and UPs. Under this scenario, for each funding source, administrators will like to increase its research contributions. Because the funding sources vary with regard to their own research objectives, the strategies that the administrator employs to gain this increase will vary depending on the funding source.

To increase state and federal contributions, the ARS and SAESs could either develop technologies that reduce farm production costs or that increase consumer welfare and the income of influential farmers and agribusiness. Thus, the director would want to maximize total social benefits. Measurements of recent research productivity and possible social benefits from this research could help determine where these benefits would be highest. In addition, the director might reduce expenditures in commodities where private sector research is strong because social benefits from duplicating private research would be limited. 
Research directors would probably take a different approach to increase industry's contributions. For example, the ARS and SAESs could concentrate on research that increases the profits of agribusiness and commodity groups. More immediate increases might come if the public sector shifted resources onto topics which the private sector already helps fund.

Since the passage of PVPA, public research institutions, along with firms, can collect royalties from sales of pure line varieties of sexually propagated crops. To take further advantage of income from royalties, the ARS and SAESs may seek more market space by developing superior varieties to those that the private sector produces.

In our model, ARS and SAES administrators will consider social benefits from research, contributions from industry, and royalties from PVPCs and UPs when allocating research resources among commodities. More formally, this relationship can be written as

$$
R D_{i j}=f\left(S B_{i j}, N P R_{i j}, I N D_{i j}, P R I V_{i j}, R P_{i j}\right),
$$

where $R D$ is ARS and SAES expenditure at time $i$ on crop $j, S B$ is the expected social benefit from research, NPR is expected royalty income to SAES from research, IND is industry's funding of public research, $P R I V$ is the quantity of private research, and $R P$ is a measure of public research productivity.

The actual variables used and sources of data are shown in table 3 . However, some of the independent variables need further explanation. One common way of measuring social benefits is net social surplus (NSS) (Perrin and Foster):

$$
\begin{aligned}
N S S_{j}=c^{*} k_{j}^{*} V_{j}^{*} & \\
& {\left[1+k /\left(2 / n_{j}+2 / e_{j}\right)\right]-C_{j}(k), }
\end{aligned}
$$

where for every crop $j, c$ is a capitalization factor (which captures the present value of social benefits), $V$ is the value of production, $k$ is the percent reduction in production costs resulting from a new technology, $e$ is the elasticity of supply, $n$ is the absolute value of the elasticity of demand, and $C$ is $R \& D$ costs. We assume that $c$ is the same for all crops, so $c=1$. For simplicity, we also assume that the reduction in production costs is $1 \%$ for all five crops, so $k$ $=1$. Therefore, equation (2) becomes

$$
S B_{j}=V_{j}^{*}\left[1+1 /\left(2 / n_{j}+2 / e_{j}\right)\right]-C_{j},
$$

which we use to estimate $S B_{i j}$. Several different lag structures on the value of production were used in estimating $S B_{i j}$. However, an average over the previous five years proved to be the best lag.

Experiment station directors might also look at measures of the productivity of research programs other than $k$ such as numbers of varieties released or publications. We tried as a rough measure of research productivity $(R P)$ the number of varieties released divided by earlier research expenditure. The coefficients for all variables, with the exception of $P R I V$, are expected to be positive.

\section{Empirical Results}

Three specifications of our model [equation (1)] were estimated in linear form using OLS. Several functional forms of our model were estimated, but the linear form had the best fit. The results of the linear specifications are shown in table 4. Social benefits $(S B)$ are consistently positive and significant at the $5 \%$ or $10 \%$ level across all three specifications. Research produc-

Table 3. Variables and Data Source

Variables

Description and Data Source

Dependent variables

$\overline{R D} \quad$ Federal and SAES R\&D plant breeding and maintenance (RPAs 307 and 405 ) from CRIS data in time periods 1968, 1972, 1976, 1980, 1984, and 1988 and crops corn, wheat, soybeans, cotton, and sorghum.

Expected social benefits

$\overline{S B} \quad$ Producer and consumer benefit calculated using Perrin and Foster (see text).

RP Productivity of research for $i$ less than 1980 is the number of varieties for each $j$ released in Crop Science 1968-70 divided by the number of SYs in 1968. For $i$ greater than or equal to 1980 , the number of varieties for each $j$ from $1985-87$ was divided by the number of scientific years in 1985 .

PRIV Private expenditure on research from Perrin, Kunnings, and Ihnen; and Kalton, Richardson, and Frey. This variable was lagged in the following manner: for 1968, 1972, 1976, 1980, 1984, and 1988; private expenditures were taken from $1960,1965,1970,1975,1980$, and 1982, respectively.

SAES income generation

$\overline{N P R}$ Dummy for the PVPA is one for the self-pollinated crops in which SAES took PVPCs-wheat, soybeans, and cotton-after 1970 .

IND Industrial funding per crop per year from CRIS data. 
Table 4. Factors Influencing Public Allocation of R\&D Resources: Regression Results

\begin{tabular}{|c|c|c|c|}
\hline \multirow{2}{*}{$\begin{array}{l}\text { Independent } \\
\text { Variables }\end{array}$} & \multicolumn{3}{|c|}{ Specifications } \\
\hline & 1 & 2 & 3 \\
\hline $\begin{array}{l}\text { Social } \\
\text { benefits }(S B)\end{array}$ & $\begin{array}{l}0.00011 \\
(1.64)\end{array}$ & $\begin{array}{l}0.00034 \\
(6.884)\end{array}$ & $\begin{array}{l}0.00013 \\
(1.91)\end{array}$ \\
\hline $\begin{array}{l}\text { Research } \\
\text { productivity }(P R O D)\end{array}$ & $\begin{array}{l}-0.00003 \\
(-.059)\end{array}$ & $\begin{array}{l}0.0004 \\
(.740)\end{array}$ & $\begin{array}{l}0.00011 \\
(0.25)\end{array}$ \\
\hline $\begin{array}{l}\text { Private } \\
\quad \text { research }(P R I V)\end{array}$ & $\begin{array}{l}-0.030 \\
(-.93)\end{array}$ & & \\
\hline $\begin{array}{l}\text { Potential } \\
\text { royalties }(N P R)\end{array}$ & & $\begin{array}{r}0.0017 \\
(2.724)\end{array}$ & $\begin{array}{l}0.00075 \\
(1.38)\end{array}$ \\
\hline $\begin{array}{l}\text { Industry } \\
\quad \text { contributions }(I N D)\end{array}$ & $\begin{array}{c}6.40 \\
(4.93)\end{array}$ & & $\begin{array}{c}5.22 \\
(3.91)\end{array}$ \\
\hline Constant & $\begin{array}{l}0.0009 \\
(2.04)\end{array}$ & $\begin{array}{l}0.0003 \\
(.500)\end{array}$ & $\begin{array}{l}0.0006 \\
(1.07)\end{array}$ \\
\hline Adjusted $R^{2}$ & .828 & .648 & .77 \\
\hline Degrees of freedom & 25 & 26 & 25 \\
\hline
\end{tabular}

tivity $(R P)$ changes signs and is not significantly different from zero in any specification. Private research $(P R I V)$ has the expected sign but is not significant. However, this relationship deserves a more in-depth examination which is beyond the scope of this paper. The intellectual property rights coefficient (NPR) is positive in most specifications but is statistically significant only in specification 2. When the industry contributions variable (IND) is added (specification 3) the $R^{2}$ increased, the NPR coefficient remained positive but was no longer significant, and the $R P$ coefficient changed to the expected sign. $I N D$ is positive and significant in all specifications of the model.

The regression results support the argument that expected social benefits guide research directors in their allocation of resources. They also suggest that intellectual property rights have influenced the commodity composition of public research. They do not support the argument that research contributions by industry and commodity groups induce directors to allocate more government resources to those commodities. The industry variable is positive, but the elasticity of public research with respect to industry contributions to public research is less than one (.5 to .6 , depending on the specification). This result indicates that public research administrators substitute private contributions for public research dollars rather than spending more public research dollars to capture limited industry contributions, as some critics predicted.

\section{Conclusions}

The regression results indicate that social benefits are important in influencing the direction of research. There is some support for the argument that the new opportunities for income provided by the PVPA have influenced the direction of public research. The key policy question, however, is whether PVPA and industry contributions would result in lower social benefits.

The first column in table 5 shows the most recent (1988) allocation of public resources between the five crops in this study. If in the future resources are allocated to crops in which property rights have been improved, wheat, cotton, and soybeans would receive more resources. If public resources were allocated by the value of the seed market, they would be allocated like column 2 . The share of corn would more than double, wheat's share would be cut in half, and cotton's share would decline from $14 \%$ to $3 \%$. If resources are allocated more like contributions of private companies and commodity groups (column 3), the corn and soybeans will increase while the other crops' shares will decline. If the public sector tries to duplicate the private sector (column 4), even more emphasis would be placed on corn.

Would reallocating the public sector resources according to the value of the seed market reduce social benefits? A definitive answer is not possible here. However, if resources were allocated according to our crude measure of social benefits, they would resemble column 5 . This column suggests that public resources would shift away from wheat and cotton toward corn. Thus, if experiment stations shifted resources in the direction suggested by industry's contribution, they would also be moving toward an allocation of resources that would increase social benefits. If they allocate resources according to the value 
Table 5. Current and Potential Future Allocation of Research Resources-Selected Crops (percent of 5-crop total)

\begin{tabular}{lccccc}
\hline & $\begin{array}{c}\text { Current (1988) } \\
\text { Public } \\
\text { Allocation }\end{array}$ & $\begin{array}{c}\text { Allocation } \\
\text { Based on } \\
\text { Seed Market }\end{array}$ & $\begin{array}{c}\text { Industry } \\
\text { Contribution }\end{array}$ & $\begin{array}{c}\text { Private } \\
\text { R\&D } \\
1989\end{array}$ & $\begin{array}{c}\text { Allocation } \\
\text { Based on SB }\end{array}$ \\
\hline Corn & 25 & 58 & 34 & 68 & 40 \\
Sorghum & 8 & 6 & 6 & 6 & 4 \\
Wheat & 30 & 12 & 19 & 7 & 18 \\
Cotton & 14 & 3 & 11 & 3 & 9 \\
Soybeans & 24 & 21 & 29 & 16 & 29 \\
\hline
\end{tabular}

Sources: Column 1, CRIS; column 2 calculated from value of commercial seed in mid-1980s from Daberkow; column 3 calculated from CRIS data for 1988; column 4 calculated from Kalton, Richardson, and Frey; column 5 calculated from social benefits for 1988; see table 4 .

of the seed market or like the private sector, they might be placing too much emphasis on corn.

\section{References}

Butler, L. J., and B. W. Marion. The Impacts of Patent Protection on the U.S. Seed Industry and Public Plant Breeding. North-Central Regional Research Publication 304, Sep. 1985.

Daberkow, S. Agricultural Input Industry Indicators in 1975 85: Expansion and Contraction. Washington DC: U.S. Department of Agriculture, Economic Research Service Agr, Info. Bull. No. 534, Nov. 1987.

Hayami, Y., and V. W. Ruttan. Agricultural Development: An International Perspective. Baltimore MD: Johns Hopkins University Press, 1985.

Huffman, W. E., and J. A. Miranowski. "An Economic Analysis of Expenditures on Agricultural Experiment Station Research." Amer. J. Agr. Econ. 63(1981):10418.

Kalton, R. R., P. A. Richardson, and N. M. Frey. "Inputs in Private Sector Plant Breeding and Biotechnology Research Programs in the USA." Diversity 5(1990):2225.

Perrin, R. K., and W. Foster. "Economic Measures of the Effect of Intellectual Property Rights on Plant Breeding." Paper presented at the AAAS meetings, New Orleans LA, 18 Feb. 1990.

Perrin, R. K., K. A. Kunnings, and L. A. Ihnen. "Some Effects of the U.S. Plant Variety Protection Act of 1970.” Dep. Econ. and Bus. Econ. Res. Rep. No. 46, North Carolina State University, Aug. 1983.

Rose-Ackerman, S., and R. E. Evenson. "The Political Economy of Agricultural Research and Extension: Grants, Votes, and Reapportionment." Amer. J. Agr. Econ. 67(1985):1-14.

Ruttan, V. W. "Bureaucratic Productivity: The Case of Agricultural Research." Public Choice 35(1980):529-47.

Stallman, J. I. "Plant Patents and Public Research Priorities." Choices (1990):8-11.

Ulrich, A., H. Furtan, and A. Schmitz. "Public Returns from Joint Venture Research: An Example from Agriculture." Quart. J. Econ. 100(1986):103-29. 